\title{
Chemicals and energy from biomass
}

\author{
Lucian A. Lucia, Dimitris S. Argyropoulos, Lambrini Adamopoulos, and \\ Armindo R. Gaspar
}

\begin{abstract}
Approximately 89 million metric tonnes of organic chemicals and lubricants are produced annually in the United States (T.M. Carole, J. Pellegrino, and M.D. Paster. Appl. Biochem. Biotechnol. 115, 871 (2004)). The majority of these materials are fossil fuel based and may load the environment during use and at the end of their life cycle. Issues, such as disposal, pollution, and degradation, must be considered and weighed. As a result, the need to decrease pollution caused by petrochemical usage is currently impelling the development of green technologies. It is virtually inarguable that the dwindling hydrocarbon economy will eventually become unsustainable. The cost of crude oil continues to increase, while agricultural products see dramatic decreases in world market prices. These trends provide sufficient basis for renewed interest in the use of biomass as a feedstock and for the development of a carbohydrate-based economy as the logical alternative to fossil fuel resources.
\end{abstract}

Key words: biomass, biochemicals, natural products, bioenergy.

Résumé : Au cours d'une année, aux États-Unis d'Amérique, il se produit environ 89 millions de tonnes métriques de produits chimiques et de lubrifiants organiques. La majorité de ces produits sont obtenus à partir de combustibles fossiles et ils peuvent encrasser l'environnement durant leur cycle d'utilisation et de fin de vie. On doit donc considérer et pondérer des sujets tels que l'élimination, la pollution et la dégradation. En conséquence, la nécessité de diminuer la pollution qui est causée par l'usage des produits de l'industrie pétrochimique propulse le développement de technologies vertes. Il est pratiquement impossible de nier que l'économie basée sur les hydrocarbures ne pourra pas continuer. Le coût du brut continue d'augmenter alors que les prix des produits agricoles sur les marchés mondiaux font face à des réductions dramatiques. Ces tendances sont les bases du nouvel intérêt dans l'utilisation de la biomasse comme matière première ainsi que pour le développement d'une économie basée sur les hydrates de carbone comme alternative logique pour les ressources à base de combustibles fossiles.

Mots clés : biomasse, produits biochimiques, produits naturels, bioénergie.

[Traduit par la Rédaction]

\section{Petroleum - The current resource}

Petroleum is the most chemically versatile and important of the fossil fuels, the so-called "biomass of earlier eras" (1). Petroleum is an indispensable resource, whose availability is integral to the functioning of our modern society. However, since the energy crises of the 1970s, the world realizes all too well that petroleum is a finite resource and its availability is limited. Taking into account production and existing reserves, Hubbert (see graph in Campbell (2)) has predicted a maximum peak for oil production (Fig. 1a, and see ref. 2) whose timing ominously coincides with current increasing petroleum prices. Yet, the price of petroleum tends to fluctuate, but is very intimately related to world events (Fig. $1 b$ and see ref. 3 ).

In the United States, $40 \%$ of the total energy consumption is petroleum-based. This makes it perhaps the world's most

Received 15 March 2006. Accepted 23 May 2006. Published on the NRC Research Press Web site at http://canjchem.nrc.ca on 1 September 2006.

L.A. Lucia, ${ }^{1}$ D.S. Argyropoulos, L. Adamopoulos, and A.R. Gaspar. Department of Forest Biomaterial Science and Engineering, College of Natural Resources, North Carolina State University, Raleigh, NC 27695-8005, USA.

${ }^{1}$ Corresponding author (e-mail: lucian.lucia@ncsu.edu). important commodity, and obtaining it has been a factor in several military conflicts. Petroleum is primarily used as fuel oil (90\% by volume), such as gasoline and diesel fuel. Nonfuel uses include chemical solvents, lubricating oils, and raw feedstock (naphtha and various refinery gases) for many sundry chemicals.

\section{Biomass - The alternative resource}

The National Renewable Energy Laboratory (Golden, Colorado) defines biomass as organic matter available on a renewable basis (4). Biomass includes forest and mill residues, agricultural crops and wastes, wood and wood wastes, animal wastes, livestock operation residues, aquatic plants, fast-growing trees and plants, and municipal and industrial wastes. In general, biomass can include anything that is not a fossil fuel that is bioorganic-based.

Biomass provides a naturally abundant resource that is not only cheap but also sustainable. The bioindustry presents an environmentally friendly alternative to the petroleum industry. The productive use of waste residues allows for lower emissions to the atmosphere, since $\mathrm{CO}_{2}$ from biomass is considered neutral and could have ancillary benefits, such as providing a new source of economic growth for rural communities. Presently, the available biomass resources could provide as much as $6-10 \times 10^{15} \mathrm{Btu}(1 \mathrm{Btu}=1.055056 \mathrm{~kJ})$ 
Fig. 1. (a) Hubbert's peak oil production. (b) Ten day moving average of prices (nominal, not adjustable for inflation) of NYMEX Light Sweet Crude.
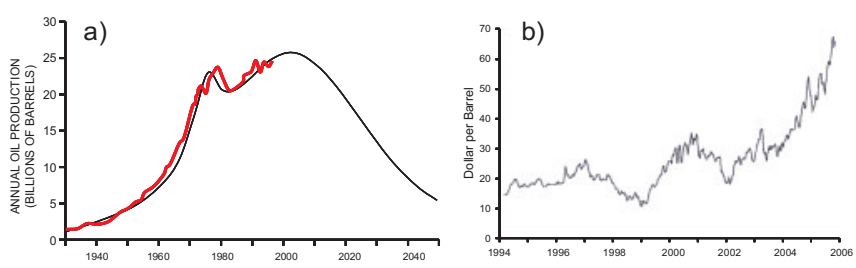

of feedstock energy. This corresponds to the energy required to manufacture over $300 \times 10^{9} \mathrm{lb}(1 \mathrm{lb}=0.45359237 \mathrm{~kg})$ of organic chemicals (4).

There exists a real opportunity to discover new ways to produce novel and quality products within the context of sustainability issues that are beginning to permeate recent industrial thinking. In this context, issues such as producing biomaterials from renewable natural resources, are at the forefront. As fossil fuel feedstocks are irreversibly diminishing, environmental pressures are escalating, and the availability of inexpensive crude oil is coming to an end (5-7); thus, the evolution to renewable feedstocks for energy and chemicals seems inevitable $(7,8)$. The biomass technologies, therefore, have an opportunity to become competitive.

The combustion of fossil fuels contributes to carbon dioxide accumulation in the atmosphere. Its accumulation and deforestation activities are the main culprits behind radical climactic changes in the global environment (9). During the 1990s, annual greenhouse gas emissions to the atmosphere from the burning of fossil fuels was $6.3 \mathrm{Gt}$ (in carbon units) $(1 \mathrm{t}=1000 \mathrm{~kg})$ and emissions from deforestation activities was an additional $1.6 \mathrm{Gt}(10,11)$. Furthermore, it has been estimated that the annual increase of $\mathrm{CO}_{2}$ to the atmosphere is $3.3 \mathrm{Gt}$ as carbon (12). The remaining $4.6 \mathrm{Gt}$ is absorbed annually by the world's oceans and terrestrial vegetation (11). Figure 2 (see refs. 10-12) is a representation of the carbon cycle mass balance.

Bioproducts are industrial and consumer goods manufactured wholly or in part from renewable biomass. They are mainly created from primary resources, which are corn, wood, soybeans, and plant oils. The tremendous diversity of bioproducts, ranging from paper to solvents to pharmaceuticals, makes them an integral part of our lives.

Variations in the definition of what should be considered a bioproduct are responsible for disparities in the estimates of the annual usage of biomass in the manufacture of industrial and consumer products. The National Renewable Energy Laboratory estimated that about $21 \times 10^{9} \mathrm{lb}$ of biomass were used in 2001 (4). On the other hand, the estimate by Energetics Inc. (Columbia, Maryland) was much more conservative, approximately $12.4 \times 10^{9} \mathrm{lb}$ for 2001 (4).

The thousands of different industrial bioproducts produced today can be considered as stemming from sugar and starch, oils and lipids, gum, wood, and finally cellulose (4, 13-16). Annual production of industrial corn starch products is estimated to be $6500 \times 10^{6} \mathrm{lb}$, which corresponds to an estimated value of $\$ 2200$ million US. Industrial ethanol production is estimated at $3.41 \times 10^{9} \mathrm{lb}$, with an estimated value of $\$ 961$ million US. Oil- and lipid-based bioproducts include fatty acids and oils derived from soybeans, rapeseed,
Fig. 2. Mass balance of the carbon cycle during the 1990s.

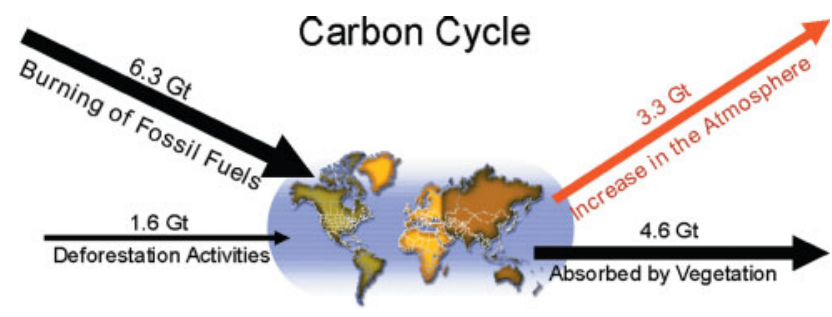

or other oilseeds. Four hundred million pounds of glycerine, equivalent to $\$ 320$ million US, are produced annually. Over $1200 \times 10^{6} \mathrm{lb}$ of soy oil, peppermint, spearmint, and other plant oils produced annually have an estimated value of $\$ 550$ million US. Gum and wood chemicals include tall oil, alkyd resins, rosins, pitch, fatty acids, turpentine, and other chemicals derived from trees. The annual production of these is approximately $3200 \times 10^{6} \mathrm{lb}$. The value of these is estimated at $\$ 890$ million US. Cellulose derivatives, fibers and plastics, include products such as cellulose acetate (cellophane) and triacetate, cellulose nitrate, alkali cellulose, and regenerated cellulose. The primary sources of cellulose are bleached wood pulp and cotton linters. Cellulose derivatives have an annual production of $2140 \times 10^{6} \mathrm{lb}$. Their estimated value is $\$ 1400$ million US.

The use of biomass for energy, materials, and chemicals parallels the concept of the biorefinery, as well as that of sustainability. A biorefinery is a facility that integrates biomass conversion processes and equipment to produce fuels, power, heat, and high-value chemicals from biomass. Byproducts, residues, and a portion of the produced fuels would be used to fuel the biorefinery itself. A biorefinery might produce transportation fuels (low-value product) in high volumes, high-value chemicals in low volumes, while generating electricity and process heat for its own use, and perhaps produce surplus electricity for sale into the power grid. The high-value products enhance profitability, the highvolume fuel helps meet national energy needs, and the power production reduces costs and avoids greenhouse gas emissions.

The pulp and paper industry has been practicing aspects of the biorefinery philosophy almost since its inception. Indeed, wood is converted into pulp for papermaking and black liquor (liquid phase containing the organic material from wood and the chemicals after the pulping process) is used in the recovery furnace for power and steam generation, while the tall oil is sold for conversion into high-value chemicals. However, one of the unifying themes in all of their biomaterials efforts is the redefinition of the pulp mill as a biorefinery, i.e., a conceptualized site that provides biobased resources and energy that are usually outside the scope of traditional functions. Figure 3 illustrates this concept using a flow diagram. The pulp and paper mill participates in the biorefinery concept by providing raw feedstock (by-products, such as hemicellulose, extractives) that may be chemically converted into a variety of fine chemicals, polymers, and other materials.

For example, Archer Daniels Midland Co. is a chemical company that has an expanded biorefinery in Decatur, Illinois. Their large corn wet-milling plant produces industrial enzymes, lactic acid, citric acid, amino acids, and ethanol. 
Fig. 3. Flow diagram that represents the biorefinery concept in pulp, paper, agricultural residues, and related biomass.

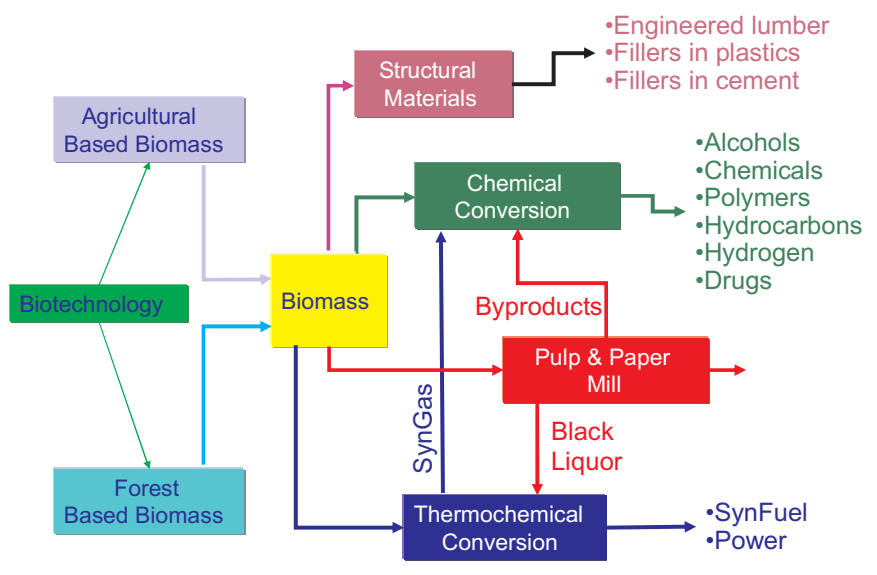

Electricity and steam are obtained through an on-site cogeneration system.

Another company that has received a lot of attention for its biorefinery is Cargill Dow $(17,18)$. Their polylactide facility in Blair, Nebraska, currently relies on corn grain for glucose, which it converts to lactic acid. The plant capacity is $300 \times 10^{6} \mathrm{lb}$, and they project a possible market of $8 \times$ $10^{9}$ lb by 2020 .

With the right technology, abundant biomass resources may be converted into valuable bioproducts and energy. Also, the development of low-cost enzymes and recombinant technologies allows for the engineering of exemplary microbes. These should also be examined in conjunction with chemicals derived from biomass, as they are an essential part of the biorefinery.

\section{Biobased chemicals vs. parallel petrochemicals}

Cellulosic biomass or lignocellulosics from plants can be a raw source of sugars for industrial processes. The use of this biomaterial presents several advantages. Theoretically, cellulose and lignin are a less expensive feedstock than petroleum. Moreover, its use would not affect food supplies and chemicals derived from lignocellulosics would have a lower impact on the environment than petrochemicals. Additionally, cellulosic biomass is considered carbon dioxide neutral since its burning does not add any carbon to the atmosphere, beyond what was required for the plant to grow. This makes it a very green, environmentally friendly alternative to fossil fuels.

Presently, only $5 \%$ of all global chemical sales are made up of green products derived from natural resources. Nevertheless, this market share has the potential to rise as high as $20 \%$ by 2010 and may reach two-third of the total global economy, if technological advances, low-cost enzymes, and new recombinant technologies are made available on a large scale. Consequently, the potential benefits of a bioindustry are enormous and alternate biobased routes for the synthesis of traditionally petrochemically derived products should be carefully examined.

The Pacific Northwest National Laboratory, North Richland, Washington, took part in a collaborative study with the National Renewable Energy Laboratory in an effort to identify the top-tier building block chemicals for biorefineries (19). The top twelve chemicals (Fig. 4) were selected based on their compatibility with existing petrochemical processing as well as their ease of synthesis. The compounds are 1,4 diacids (succinic, fumaric, and malice), 2,5-furandicarboxylic acid, 3-hydroxypropionic acid, aspartic acid, glucaric acid, glutamic acid, itaconic acid, levulinic acid, 3-hydroxybutyrolactone, glycerol, sorbitol, and xylitolarabinitol. These molecules have six to twelve carbon atoms and multiple functional groups. Examining some of these is worthwhile in the effort to show different synthesis pathways for the same product, as well as product derivatives.

\section{Different synthesis pathways for succinic acid}

Succinic acid $\left(\mathrm{C}_{4} \mathrm{H}_{6} \mathrm{O}_{4}\right)$ occurs frequently in nature in animal tissues, vegetables and fruits, and in amber (20). Succinic acid and its salts may serve as building blocks for numerous chemical intermediates and end products (Fig. 5 and see ref. 21) in industries producing food and pharmaceutical products, surfactants, detergents, green solvents, and biodegradable plastics. Reaction with glycols gives polyesters, and specifically, esters formed by reaction with monoalcohols are important plasticizers and lubricants (22).

The total market for succinic acid is more than $\$ 400$ million US per year (21). Currently, the food market is the only one using succinic acid produced by fermentation. For other uses, succinic acid is, to a large extent, produced petrochemically from butane through maleic anhydride. Succinic acid can be produced by hydrogenation of maleic acid, maleic anhydride, or fumaric acid with standard catalysts, such as Raney nickel, $\mathrm{Cu}, \mathrm{NiO}$, or $\mathrm{CuZnCr}, \mathrm{Pd}-\mathrm{Al}_{2} \mathrm{O}_{3}, \mathrm{Pd}-$ $\mathrm{CaCO}_{3}$, or Ni-diatomite (22).

Succinic acid is a common metabolite for plants and microorganisms. It is derived through the fermentation of glucose and is a very green technology because it is $\mathrm{CO}_{2}$ fixing. Succinate is formed from sugars or amino acids by propionate-producing bacteria, such as the genus Propionibacterium, gastrointestinal bacteria such as Escherichia coli, and rumen bacteria such as Ruminococcus flavefaciens.

For the rumen ecosystem, succinate is an important precursor for propionate, which after oxidation, provides energy and biosynthetic precursors to the animal. Rumen microorganisms are major cellulose-digesting anaerobes that produce acetic and succinic acids in the rumen (23). Actinobacillus succinogenes $130 \mathrm{Z}$ is a ruminal anaerobic bacterium that is capable of producing very high concentrations of succinate from many different substrates, such as glucose, maltose, mannose, sucrose, cellobiose, and D-xylose (24).

Actinobacillus succinogenes uses the phosphoenolpyruviate (PEP) carboxykinase pathway to produce succinic acid (see Fig. 6 and ref. 25). Four key enzymes come into play, PEP carboxykinase, malate dehydrogenase, funarase, and fumarate dehydrogenase. The pathway used for succinic acid production, in which PEP carboxykinase fixes $\mathrm{CO}_{2}$ and synthesizes oxaloacetate from phosphoenolpyruvate, is regulated by $\mathrm{CO}_{2}$ levels. At low $\mathrm{CO}_{2}$ levels $\left(10 \mathrm{~mol}\right.$ of $\mathrm{CO}_{2}$ per 100 mol of glucose), A. succinogens produces mostly ethanol. At high $\mathrm{CO}_{2}$ levels $\left(100 \mathrm{~mol}\right.$ of $\mathrm{CO}_{2}$ per $100 \mathrm{~mol}$ of glu- 
Fig. 4. Chemical building blocks from biomass compatible with existing petrochemicals.

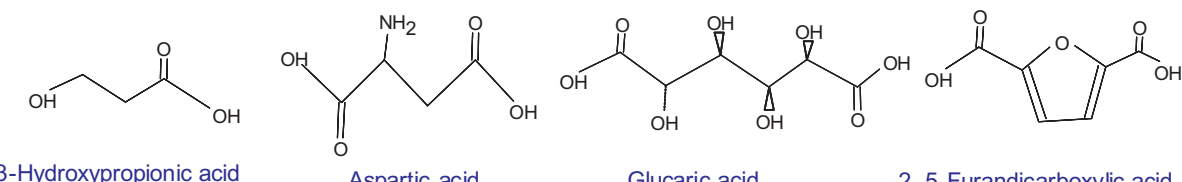

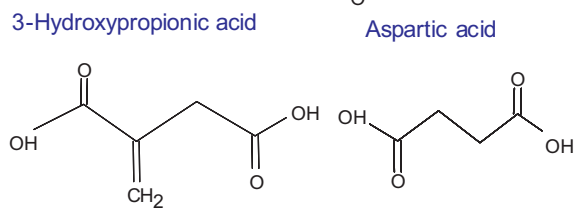

Itaconic acid Succinic acid<smiles>O=C(CO)C(=O)C(O)CO</smiles><smiles>O=C1CC(O)CO1</smiles>

Sorbitol 3-Hydroxybutyrolactone<smiles>OCC(O)CO</smiles>

Glycerol<smiles>CC(=O)CCC(=O)O</smiles>

Levulinic acid<smiles>O=C(CO)C(=O)C(=O)CO</smiles>

Xylitol<smiles>N=C(CCC(=O)O)C(=O)O</smiles>

Glutamic acid

Fig. 5. Map of routes to succinic acid based products.

Commodity Chemicals

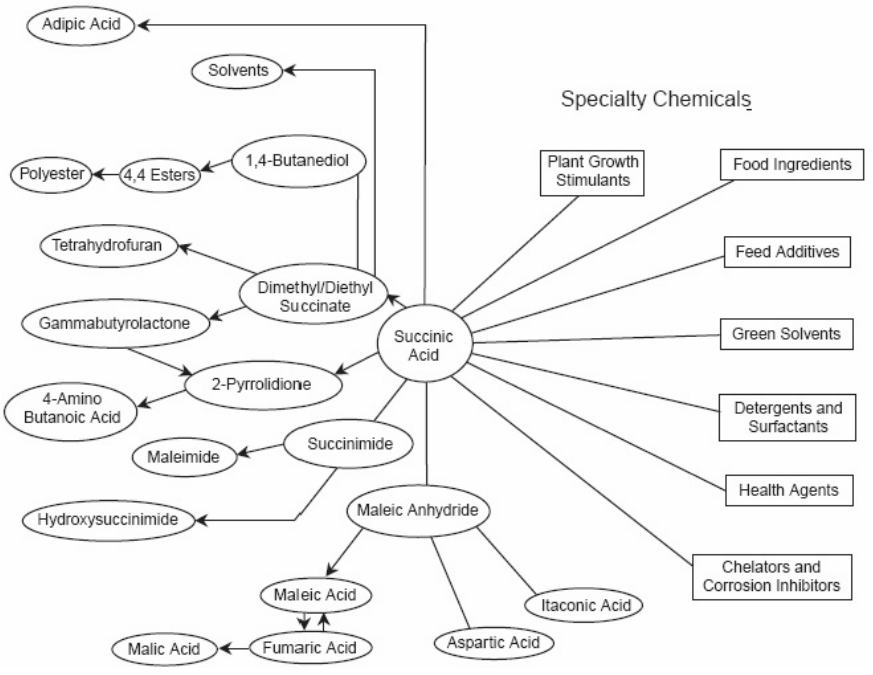

cose), succinate is the major product with only trace amounts of lactic acid or ethanol.

In actuality, the $\mathrm{CO}_{2}$ concentration regulates the levels of the key enzymes in the pathway, thus determining what the majority product will be. At high $\mathrm{CO}_{2}$ levels, phosphoenolpyruvate carboxykinase levels rise and alcohol dehydrogenase and lactate dehydrogenase are imperceptible. The $\mathrm{CO}_{2}$ functions as an electron acceptor and PEP flows to succinate at high levels.

Most fermentation organisms are not tolerant of acidic conditions and the fermentation is usually neutralized to obtain a salt of succinic acid. This must then be separated, recovered, and reacidified to form free succinic acid. Significant research in microbial production of succinic acid has resulted in the development of a strain of $E$. coli, AFP111, which shows greatly improved productivity, and fermentation using this microorganism has been successfully tested at a commercial scale (4). Moreover, the development of a two-stage desalting and water-splitting electrodialysis system has facilitated the seperation, concentration, purification, and acidification of the product (26).
Fig. 6. Proposed catabolic pathway for glucose fermentation in Actinobacillus succiniciproducens and A. succinogens. Steps:

(1) phosphoenolpyruviate carboxykinase, (2) malate dehydrogenase, (3) fumarate reductase, (4) pyruvate kinase, (5) pyruvate ferredoxin oxidoreductase, (6) acetate kinase, (7) alcohol dehydrogenase, (8) lactate dehydrogenase.

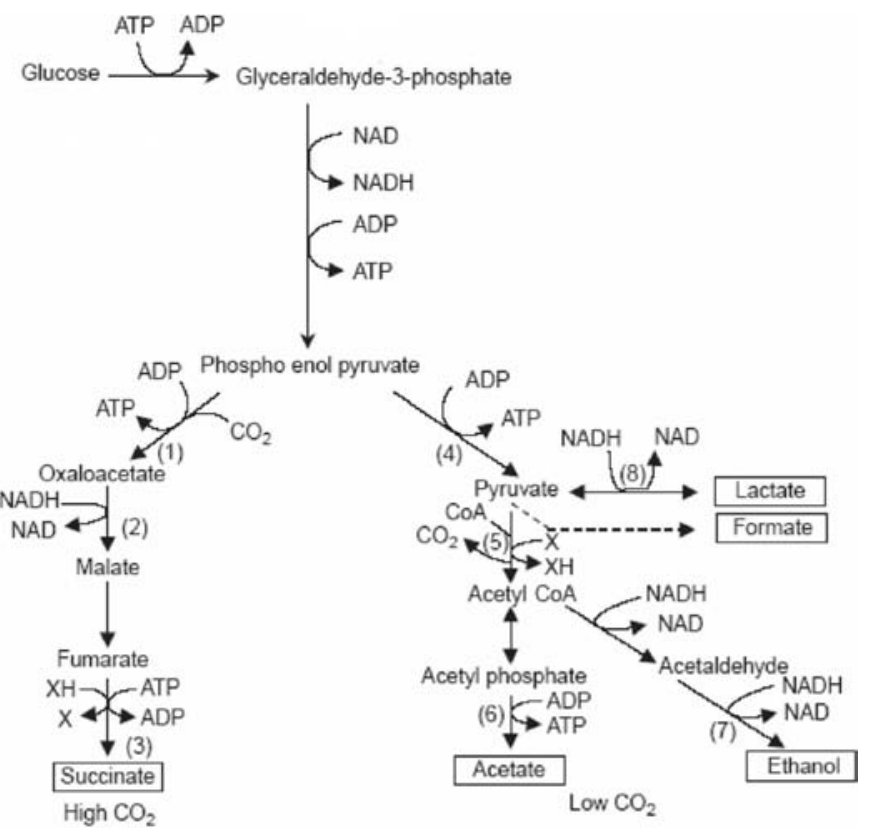

In 1992, fermentation production costs for succinic acid ranged from $\$ 1.50 \mathrm{US}$ to $\$ 2.00 \mathrm{US}$ per $1 \mathrm{~b}$ (4). Advances in fermentation and especially separation technology for the biobased route have reduced the potential production costs to about \$0.50US per pound (21). Further improvements in separation and fermentation technologies could drop the production costs even more, enabling commodity scale production. This would allow for the expansion of current markets and for opportunities in new markets.

\section{Different synthesis pathways for itaconic acid}

Itaconic acid (2-methylenebutanedioic acid) is an unsaturated dicarbonic acid. It can be regarded as an $\alpha$-substituted 
acrylic of methacrylic acid and may serve as a substitute for these petrochemical-based chemicals. On account of its two carboxyl groups, itaconic acid may easily be incorporated into polymers.

Currently, polymerized methyl, ethyl, or vinyl esters of itaconic acid are used as plastics, adhesives, and coatings. Also, it is used as a comonomer in rubberlike resins and in the manufacture of emulsion paints, where it improves the adhesion of the polymer. Acrylic lattices are supplemented with itaconic acid and used as nonwoven fabric binders. Furthermore, itaconic acid may have agricultural, pharmaceutical, and medicinal applications. It is used as a hardening agent in organosiloxanes for use in contact lenses. In addition, mono- and di-esters of partly substituted itaconic acid possess analgesic properties and some also present plant growth related activities.

The first synthesis of itaconic acid was by pyrolysis of citric acid and anhydride hydrolysis (S. Baup. Ann. Chim. Phys. 19, 29 (1837)) (Fig. 7 and ref. 27). Similarly, chemical synthesis is mainly carried out by dry distillation of citric acid and treatment of the anhydride with water. However, use of itaconic acid has been limited because the petroleum route is still expensive. It cannot compete with the fermentation of carbohydrates by fungi as a source of itaconic acid. In fact, approximately $15000 \mathrm{t}$ of itaconic acid are produced annually by fermentation. Production rates do not exceed $1 \mathrm{~g} \mathrm{~L}^{-1} \mathrm{~h}^{-1}$ and production concentrations of $80 \mathrm{~g} \mathrm{~L}^{-1}$ (28). This makes itaconic acid an expensive product, whose use is therefore limited.

The biosynthesis of itaconic acid most probably happens through glycolysis, followed by the tricarboxylic acid cycle. Citric acid and aconitic acid are intermediates. Enzymatic decarboxylation of the latter allows for the formation of itaconic acid (Fig. 8 and ref. 28).

The most frequently used commercial application of itaconic acid is the cultivation of Aspergillus terreus with molasses. Molasses products are less expensive than other kinds of carbohydrates, but the cost of itaconic acid is still high because molasses contain many impurities that are not consumed by microorganisms. So, downstream processing and waste treatment therefore become expensive. Thus, alternate carbon sources are being examined. The best yields of itaconic acid are achieved with glucose or sucrose, but these are expensive raw materials. Raw starch materials show particular potential as a substitute to molasses. Itaconic acid was produced by $A$. terreus $\mathrm{TN}-484$ in a medium containing raw corn starch $\left(140 \mathrm{~g} \mathrm{~L}^{-1}\right)$ at $\mathrm{pH} 2.0$, hydrolyzed with nitric acid at a concentration of more than $60 \mathrm{~g} \mathrm{~L}^{-1}$ in a $2.5 \mathrm{~L}$ air lift bioreactor (29).

Efforts are also being made in the selection of different microorganisms, such as various Ustalgo and Candida species. Furthermore, mutant microorganisms are also being produced and used to increase yields and biomass immobilization is being considered.

Finally, fermentation conditions are important and must be optimized. The itaconic acid fermentation is most favorable under phosphate-limited growth conditions at sugar concentrations between 100 and $150 \mathrm{~g} \mathrm{~L}^{-1}$. During fermentation, the $\mathrm{pH}$ drops to 2.0 and itaconic acid becomes the main product. The temperature is normally kept at $37{ }^{\circ} \mathrm{C}$, but certain mutated microorganisms may perform better at higher
Fig. 7. Thermal decomposition of citric acid.

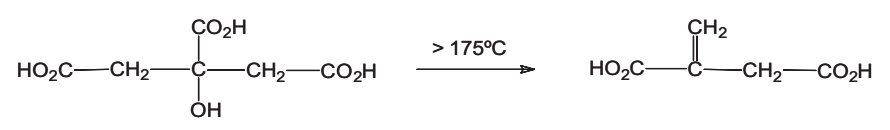

temperatures. Also, aerobic conditions are required and culture medium components, such as $\mathrm{Fe}, \mathrm{Mn}, \mathrm{Mg}, \mathrm{Cu}, \mathrm{Zn}, \mathrm{P}$, and $\mathrm{N}$, must be carefully monitored.

The market for itaconic acid is still growing because of the possibilities of substituting it for acrylic and methacrylic acid in polymers. Moreover, its potential production from agricultural plant biomass makes it an attractive biofriendly alternative. It also provides a source of inexpensive raw feedstock. Efforts in effectively utilizing such waste, as well as the introduction of new technologies, are required for reducing itaconic acid production costs and market expansion.

\section{Synthetic pathways for levulinic acid}

Levulinic acid $\left(\mathrm{H}_{8} \mathrm{C}_{5} \mathrm{O}_{3}\right)$, also known as $\gamma$-ketovaleric acid, $\beta$-acetylpropionic acid, or 4-oxopentanoic acid, is a short chain fatty acid with a ketone carbonyl group and an acidic carboxyl group. These two highly reactive functional groups make it a highly versatile chemical capable of serving as a building block for other chemicals (Fig. 9 and ref. 30). Levulinic acid is the starting compound for many heterocycles. It can be used as a raw material for resins, plasticizers, textiles, animal feed, coatings, and antifreeze. It is an auxiliary in electroplating and levulinic acid esters are used in cosmetics.

Industrially, levulinic acid is prepared from wood processing and agricultural wastes. It basically hails from the transformation of hexose sugars in acidic media. The hexoses are obtained by the hydrolysis of cellulose at atmospheric pressure with strong acids, such as $\mathrm{HCl}$ and $\mathrm{H}_{2} \mathrm{SO}_{4}$, at $100{ }^{\circ} \mathrm{C}$. The hydrolysate is then heated to $110{ }^{\circ} \mathrm{C}$ with $20 \% \mathrm{HCl}$ and kept at this temperature for 1 day. Free halogens, as well as transition metals and anion-exchange resins, accelerate the process.

Initially, the intermediate compound 5-hydroxymethyl furfural is formed from the hexoses. This happens through a series of reactions (Fig. 10 and ref. 31). The first step is the enolization of D-glucose, D-mannose, or D-fructose in acidic media to give the enediol. Next, this compound is dehydrated to the enol form of 3-deoxyhexosulose. This substance then produces 3,4-dideoxyglycosulosene-3, which is converted to the dienediol that results in 5-hydroxymethylfurfural (31).

5-Hydroxymethylfurfural can then be converted to levulinic acid by addition of a molecule of water to the $\mathrm{C} 2-\mathrm{C} 3$ bond of the furan ring. The ring opens and an unstable tricarbonyl intermediate is formed, which is finally decomposed to formic and levulinic acids (Fig. 11 and ref. 31). Levulinic acid is isolated from the mixture with a yield of approximately $40 \%$ with respect to the hexose content (31). Furthermore, for each levulinic acid molecule generated, a formic acid molecule is also created and insoluble residues, including humics, are produced.

Furthermore, levulinic acid can be synthesized starting from furfuryl alcohol (Fig. 12 and ref. 31). Heating furfuryl alcohol in aqueous organic acids in the presence of hydrochloric acid allows an $80 \%$ yield of levulinic acid. The yield 
Fig. 8. Biosynthesis of itaconic acid.

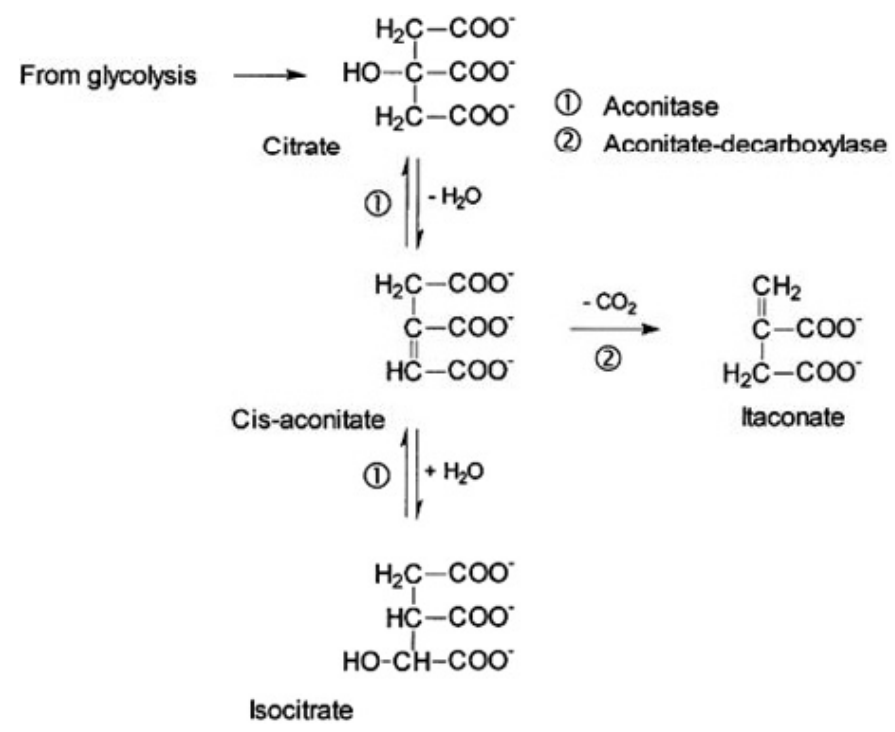

Fig. 9. Principal reactions of levulinic acid and relationships among its derivatives.

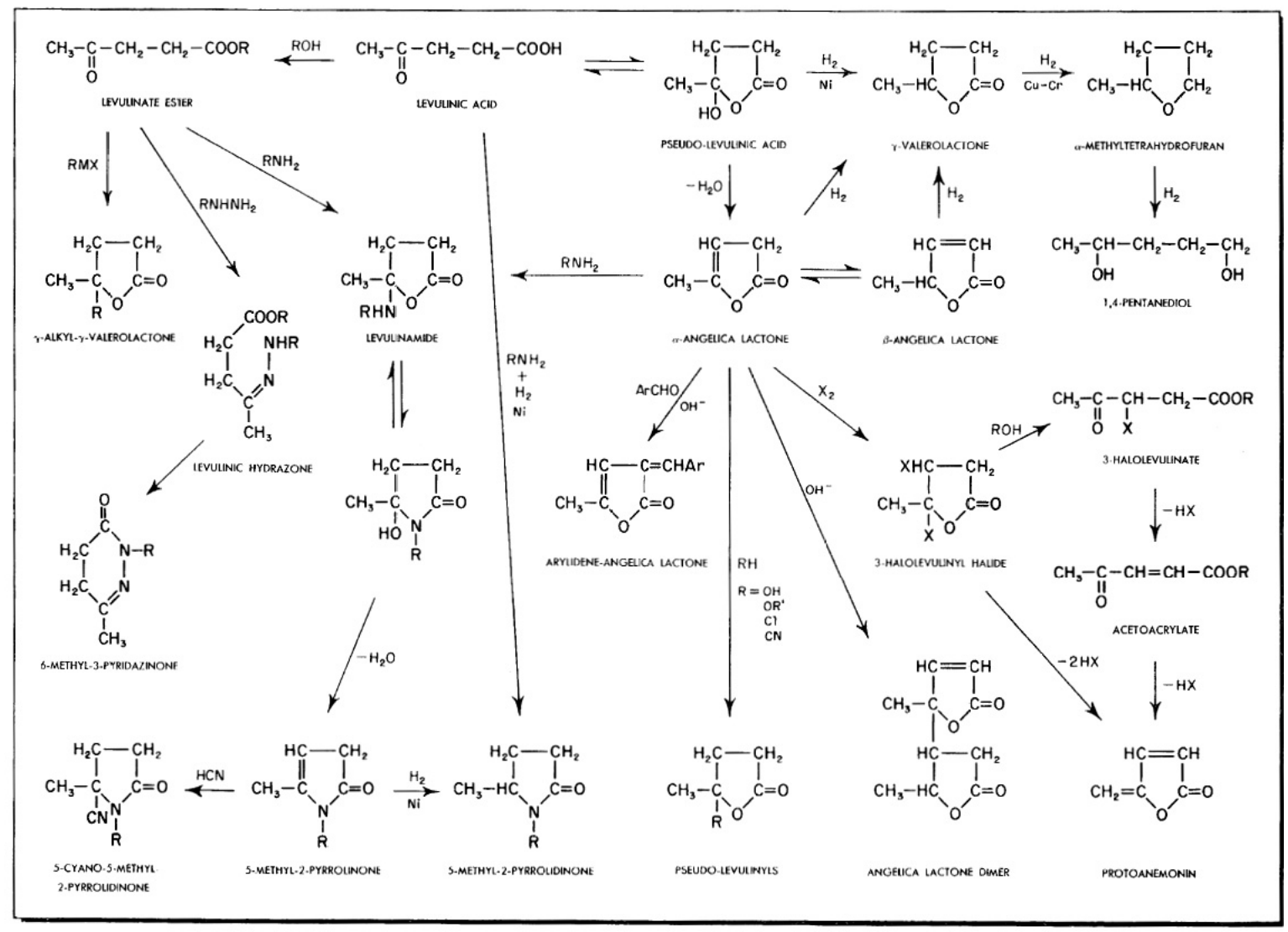

can be increased to approximately $90 \%$ when the reaction is performed in boiling ethyl methyl ketone.

Moreover, the oxidation of 5-methylfurfural with $28 \%$ $\mathrm{H}_{2} \mathrm{O}_{2}$ at $60{ }^{\circ} \mathrm{C}$ in the presence of $\mathrm{HCOOH}$ produces levulinic acid, as well as 4-oxopent-2-enoic acids (Fig. 13 and ref. 31). Levulinic acid can also be formed in high yields from the reaction of 4-(diphenylmethylsilyl)butyrolactone with MeMgI.
Levulinic acid can also be prepared from biomass, such as rice, straw, paper, and cotton (32). In this case, biomass is reacted at $40-240{ }^{\circ} \mathrm{C}$ for $1-96 \mathrm{~h}$ in the presence of $5 \%-90 \%$ sulfuric acid. Another substrate that can be used for levulinic acid production is sorghum grain. It has low cash value when sold as a feed grain and is a major source of carbohydrates. Pentosans, starch, and cellulose make up $80 \%-85 \%$ of the sorghum grain. Flour made from this grain at a $10 \%$ 
Fig. 10. 5-Hydroxymethylfurfural (8) obtained from D-glucose (9), D-mannose (10), or D-fructose (11).
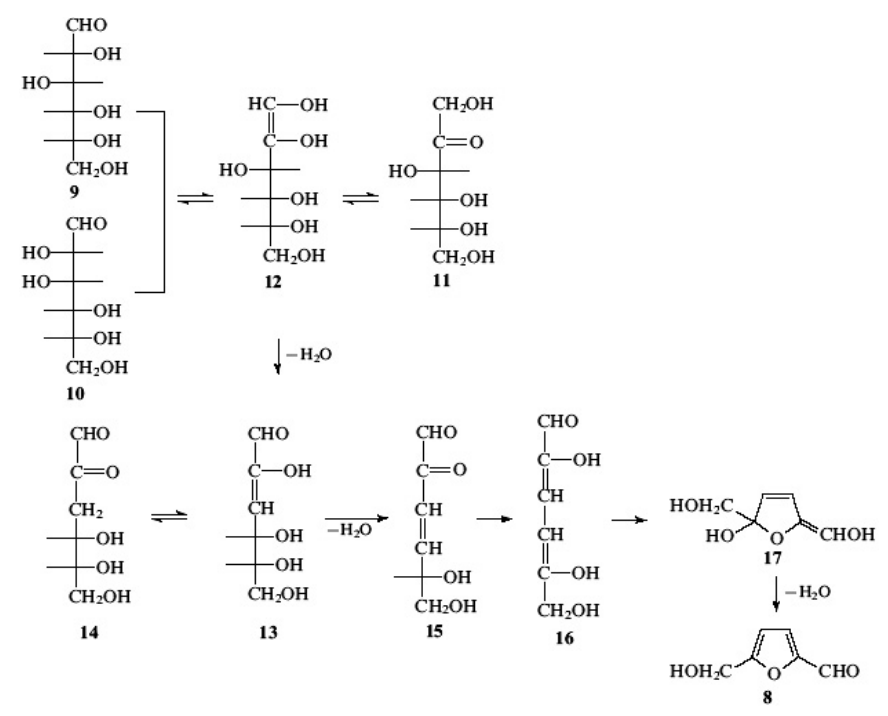

Fig. 11. 5-Hydroxymethylfurfural to levulinic acid.

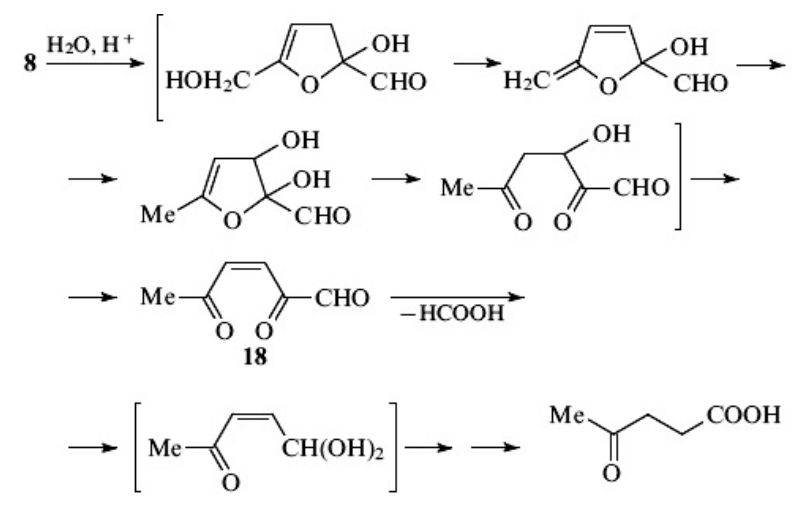

loading and blended with $8 \%$ sulfuric acid gives a yield of approximately $33 \%$ levulinic acid at $200{ }^{\circ} \mathrm{C}$ (33).

Finally, a two-step dilute mineral acid hydrolysis is available, the Biofine process (34), to break down biomass containing lignocellulose into intermediate chemicals. It was developed by BioMetics Inc. (Camarillo, California), with funding from the US Department of Energy. This hightemperature, dilute acid hydrolysis process fractionates lignocellulosic biomass into platform chemicals. The primary fractions of the process are levulinic acid, formic acid, furfural, and a bone dry char. The char residue contains approximately $11000 \mathrm{Btu}$ per $\mathrm{lb}$ and is a suitable feedstock for gasification.

BioMetics has operated a small commercial demonstration unit in New York State for four years and has just completed the first large-scale commercial facility in Italy. This large-scale facility will produce levulinic acid for monomer use, oxygenated diesel esters, and formic acid based solvents. The char residue will be converted to synthesis gas that will be burned in a gas engine to generate electricity. Approximately $0.5 \mathrm{lb}$ of levulinic acid is produced per $\mathrm{lb}$ of cellulose processed (4). Currently, levulinic acid has a worldwide market of about $1.0 \times 10^{6} \mathrm{lb}$ per year at a price of
Fig. 12. Levulinic acid from furfuryl alcohol (19).

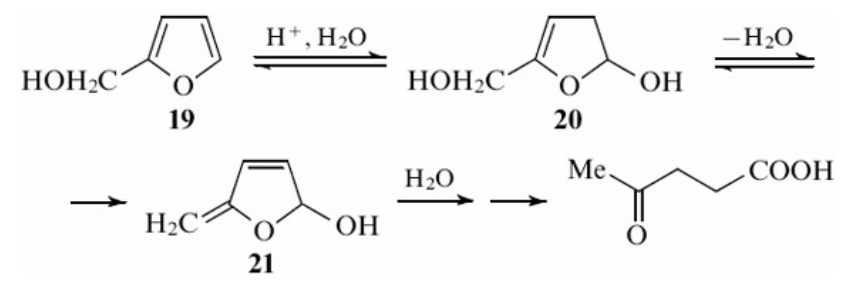

Fig. 13. Oxidation of 5-methylfurfural (22) to levulinic acid.

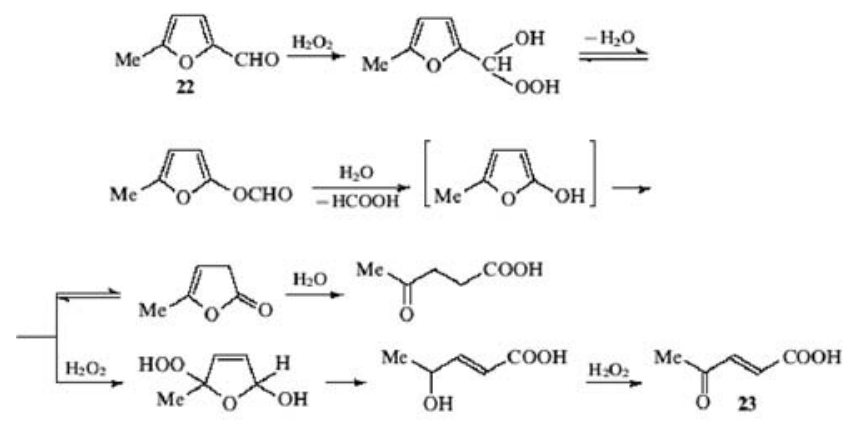

\$4US-\$6US per lb (35). Large-scale commercialization of the Biofine process could produce levulinic acid for as little as $\$ 0.32$ per lb (35), spurring increased demand.

In parallel with the process development program, BioMetics has an ongoing program aimed at expanding commercial markets for the chemical derivatives of levulinic acid in cooperation with New York State, Rensselaer Polytechnic Institute (Troy, New York), the National Renewable Energy Laboratory, the Pacific Northwest National Laboratory, and major chemical companies.

This effort has allowed for the development of a one-step catalytic process facilitating the conversion of levulinic acid to methyl tetrahydrofuran (MTHF) approved for P-series alternative fuel formulations (36). Also, it has provided a low cost route to the herbicide and plant growth regulator, $\delta$ aminolevulinic acid. New polycarbonate resin formulations using diphenolic acid are being examined and a new oxygenated diesel additive (ethyl levulinate) that reduces particulate matter emission has been developed.

The Biofine process allows for the manufacture of many high-value chemical and fuel products from cheap lignocellulosic biomass. This process is fast and continuous and is capable of utilizing a wide range of biomass feedstocks. Moreover, the gasification of the char covers the entire energy needs of the plant, making it self-sufficient. Finally, the process can be retrofitted into existing plants.

Levulinic acid is a compound that has many industrial applications. Its efficient preparation from biomass has many avenues. Its efficient extraction from decomposition products of natural materials would prove to be worthwhile for both industry and the environment.

\section{Sample reactions for high-value chemicals}

As opposed to many synthetic chemicals, forest-based and agricultural biomaterials are readily renewable, inexpensive, and environmentally benign. Despite a significant amount of recent research for augmenting the industrial use of readily 
Fig. 14. Shown in the top structure is the natural product extract, tulapilin A (A- $\alpha$-methylenebutyrolactone), found in tulips, and in the lower structure is its synthetic analogue, methyl methacrylate. Notice the strong chemical structural similarity in both the monomer and polymer.

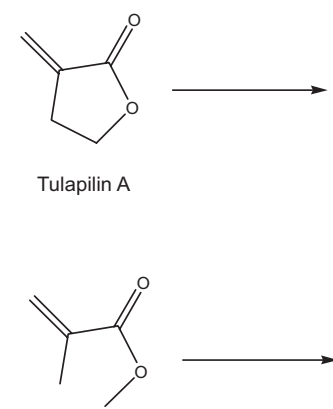

Methyl Methacrylate

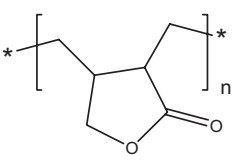

Polytulapilin

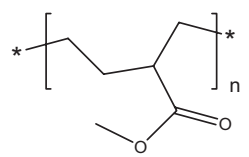

Poly(methyl methacrylate) available carbohydrates as raw materials (37-42) (e.g., car moldings, cosmetics, food, and additives), the systematic exploitation of this vast resource, as already indicated, is still in its infancy. Since clean air pressures are mounting and while the availability of cheap and abundant fossil fuel becomes increasingly questionable, as seen in the current climate, it is likely that any economic advantages for a petrochemical-based economy will literally evaporate within the next 50 years.

For example, DuPont has determined that once the price point at which an extract from plants, tulipalin $\mathrm{A}(\mathrm{A}-\alpha-$ methylenebutyrolactone) shown in Fig. 14, becomes competitive with its commercial analogue, methyl methacrylate (MM), the natural material will be used commercially for polymer applications (43). MM is a feedstock that is used for polymerization to manufacture a number of plastics, moldings, and related materials. Its natural analogue (tulapilin A) produces a polymer whose durability and refractive index rival that of MM (43). Remarkably, DuPont has also found that limonene, a citrus tree extractive, mimics the chemistry of 4-vinyl-1-cyclohexene in that it can be used as an anchoring point for the introduction of alkoxylsilanes for exterior coatings (43).

An early example of a biobased green solvent is a new class of chiral ionic liquids that can be derived from $\alpha$ pinene, an extract from pine trees, as shown in Fig. 15. Ionic liquids are salts that are liquid at or near room temperature. As such, they are composed of an anion and a cation, like any salt, but they do not have the high melting points typical of such species. Since the combination of organic cations and anions is virtually limitless, several classes of ionic liquids have actually been reported, with more and more such systems being continually discovered.

\section{Energy derived from biomass}

Since antiquity, biomass has been used by humanity as a source of energy, mainly for heating. Nowadays, new developing energy technologies are broadening the use of biomass well beyond simple combustion for heating. The conversion processes used on biomass feedstock allow the generation of steam and electric power, as well as a wide range of energy
Fig. 15. Structure of $\alpha$-pinene, a natural extractive from pine trees, which can be converted to two distinct chiral ionic liquids.

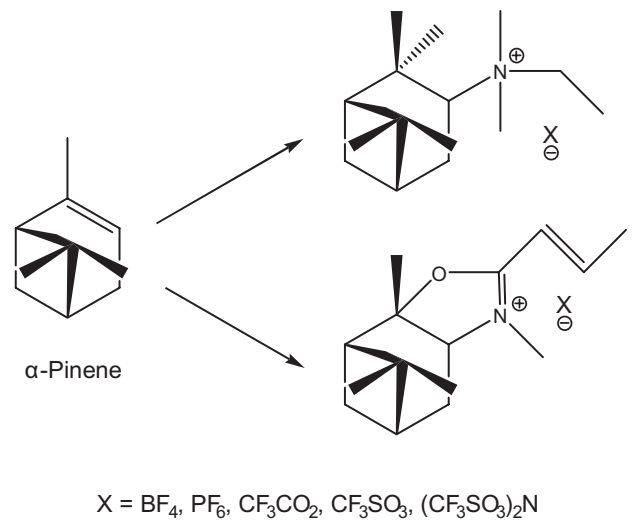

products, such as ethanol, biodiesel, fuel gas, and chemical intermediates and products. The conversion of biomass feedstock into energy products are well-established technologies, with enhanced improvements in the last decades. This subject was reviewed by Paisley (44).

\section{Steam and electric power}

Biomass has been used for simple heating by direct combustion, which by nature is a very low efficient operation ( $\sim 7 \%$ for an open fireplace and $\sim 15 \%$ for a fireplace with convective tubes) (45). Efficiency improvements are realized by larger scale combustion processes in boilers or furnaces, thus improving heat recovery, and therefore, overall efficiency.

Boiler applications further provide the opportunity to generate electrical power from the incoming biomass. The biomass is burned to generate steam, which is then used to turn a turbine to generate electric power. The majority of the biomass-based power plants are found in the pulp and paper industry. Woody residues from the wood raw material and the black liquor, a by-product from the pulping process, are consumed to generate the necessary power for plant operations. When black liquor is burned for energy recovery, the pulping chemicals are recovered and recycled, thus further reducing the costs.

Biomass-based combined heat and power (CHP) systems provide the primary energy for large segments of the population in many European countries, mainly Scandinavian and northern countries. These systems typically combust biomass to produce high-pressure steam for further electric power generation. Lower-pressure steam is then extracted from the turbine system and used for district heating.

\section{Ethanol}

Ethanol production is known historically from the manufacture of alcoholic beverages, such as wines and beers. It is produced through natural fermentation of the starch and sugars present in different forms of biomass by biological organisms. Nowadays, grains of wheat or corn (biomass materials) are typically the primary source for the production of ethanol as fuel, which can be blended with other fuels such as gasoline $(46,47)$. Other sources for ethanol 
production that are also in use are straw, sugar cane, sugar beet, and wood (48).

Large-scale production of ethanol makes use of the fermentation process as well. In a first stage, biomass material, such as corn kernel or other starchy grain, is milled through a dry or wet milling mode. The fermentation then takes place by mixing the resulting flour (biomass polysaccharides) in water with yeast. The mixture is heated at $\sim 30{ }^{\circ} \mathrm{C}$ to initiate the fermentation reactions under an anaerobic environment, and the process takes $\sim 1$ to 2 days for completion. After fermentation, the ethanol is filtered and then distilled to increase its concentration from $10 \%$ to $95 \%$. The concentrated ethanol is then blended with petroleum-based fuels to the desired concentration.

Ethanol can also be produced from cellulosic biomass such as agricultural residues, forestry residues, waste paper, yard wastes, portions of municipal residues, and industrial residues (49). The long-chain polysaccharide materials are initially treated with acid or enzymes to cleave the glycosidic bonds. The acid recovery system can be a complex process. Research is being performed to find ways to reduce the acid levels while maintaining high conversion levels. The resulting small fractions can then readily be fermented to ethanol. In parallel, small fractions of biomass can be used to grow fungi and other organisms to produce enzymes (cellulase), which hydrolyze cellulose (in pretreated biomass) to glucose. Figure 16 (see ref. 49) presents a scheme for the production of ethanol from cellulosic biomass (49). There are a variety of technologies that combine two or all three of the hydrolysis and fermentation steps within the shaded box.

US ethanol production has grown significantly in recent years. In 2004 , a record $3.41 \times 10^{9}$ gal $(1$ gal Am. $=3.79 \mathrm{~L})$ of ethanol were produced - an incredible $109 \%$ increase from 2000 (50). But ethanol plants also produce other products. Depending on the type of facility, a number of other coproducts result from ethanol production, adding even more value to corn feedstocks and to the economy. Dry mill facilities also produce distillers dried grain with solubles (DDGS) and carbon dioxide. Ethanol wet mills can also produce corn gluten meal feed, sweeteners, and corn oil. These coproducts and by-products from cellulosic biomass ethanol production can be used to produce value-added chemicals, contributing to the economy of fuel production from biomass. On the other hand, ethanol can also be used as a chemical intermediate in the production of other organic chemicals.

Oxygenated transportation fuels, such as the ethanol-gasoline blends, can benefit environmental conditions. Mixtures of up to $10 \%$ ethanol, referred to as E10, can be utilized in most gasoline engines with no modification. More concentrated blends, namely the E85 and E95 blends (85\% and $95 \%$ ethanol, respectively) require specifically designed engines, referred to as "flexible fuel" engines, to perform properly. These flexible fuel engines can run on either gasoline or high-concentration ethanol blends. Automobile manufacturers are producing more vehicles that can use these high ethanol blends each year, thus increasing demand. The spark-ignition Otto-cycle engines used in today's automobiles, even in their early stages of development, were designed to operate with ethanol-containing fuels. Henry Ford designed the early Model $\mathrm{T}$ to use ethanol as a major fuel
Fig. 16. Basic steps in production of ethanol from cellulosic biomass.

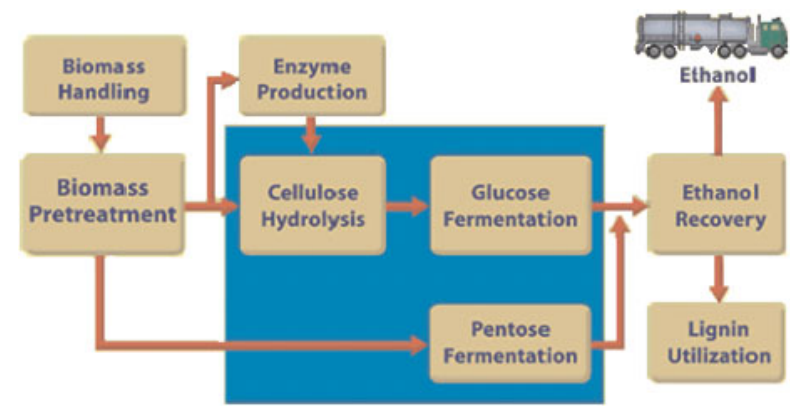

source. Such plans were subsequently changed when storage and transportation difficulties, combined with high corn prices at the time caused the supply of ethanol-containing blends to be reduced.

\section{Biodiesel}

Biodiesel is a fuel that can be made from renewable resources such as vegetable oils or animal fats. It is usually produced from soy or canola oil. Other possible resources are recycled fryer oils. Through a transesterification process, the oils are converted into biodiesel. The latter can be used as pure fuel or blended at any level with petrodiesel for use by diesel engines. Biodiesel is designated B100 and meets the requirements of ASTM D6751 (51).

Biodiesel comprises of a mix of monoalkyl esters of longchain fatty acids. A lipid transesterification reaction is used to convert the base oil to the desired biodiesel. The most common process uses methanol to produce methyl esters, although ethanol can also be used to produce an ethyl ester biodiesel. In the production of biodiesel, the triglicerides in the oils and fats are reacted with methanol (or ethanol) to make methyl esters (or ethyl esters) and glycerol as a byproduct. The process uses a catalyst, typically $\mathrm{NaOH}$ or $\mathrm{KOH}$, to enhance the reaction rates. Some oils may have to undergo some pretreatment before reaction with methanol to avoid the formation of high concentrations of free fatty acids. The reactions take place at low temperatures $\left(\sim 65{ }^{\circ} \mathrm{C}\right)$ and at modest pressures ( 2 atm, 1 atm $=101.325 \mathrm{kPa}$ ). Biodiesel is further purified by washing and evaporation to remove any remaining methanol. The oil (87\%), alcohol $(9 \%)$, and catalyst $(1 \%)$ are the inputs in the production of biodiesel $(86 \%)$, the main output. Other by-products include glycerine $(9 \%)$, alcohol (4\%), and fertilizer $(1 \%)$. Nothing is wasted in biodiesel production (52).

Biodiesel can be a direct substitute for petrodiesel, either as neat fuel (B100 or BD100) or as an oxygenate additive at any concentration, blended with diesel. Typically, the biodiesel that is primarily utilized is the B20 blend $(20 \%$ biodiesel and $80 \%$ petrodiesel). Pure biodiesel or blends can be used in any compression-ignition (diesel) engine. B20 earns credits for alternative fuel under the US Energy Policy Act of 1992. Ranges as low as $2 \%$ (BD2 or B2), have shown lubricity benefits (53). In 2004, almost $30 \times 10^{6}$ gal of commercially produced biodiesel were sold in the US, up from less than $0.5 \times 10^{6} \mathrm{gal}$ in 1999 (54). Because of increasing pollution control requirements and tax relief, the US market is expected to grow to 1 or $2 \times 10^{9}$ gal by 2010 . 
Looking back, Rudolf Diesel had successfully presented his engine powered by peanut oil (biofuel) at the World's Fair in Paris, France, in 1900, where he received the "Grand Prix" (highest prize). He believed that the utilization of biomass fuel was the real future of this engine. In a prophetic 1912 speech, Rudolf Diesel said, "the use of vegetable oils for engine fuels may seem insignificant today, but such oils may become, in the course of time, as important as petroleum and the coal-tar products of the present time" (55).

\section{Conclusions}

In retrospect, the petroleum age has served the growth of civilization quite well. However, it has also become an albatross to further growth, given its intrinsic deficiencies for environmental compatibility, sustainability, and micro- and macro-economics. As Rudolph Diesel so astutely intimated, we are now at the nexus of a major crossroads in the future of humanity with respect to the production of chemicals, materials, and energy. The only real solution that is viable and necessary is the efficient and intelligent use of biomass as derived from plant and animal residues. Capturing the chemical and material value of bioderived succinic, itaconic, and levulinic acids, as indicated in this review, will provide the world with freedom from the economic and geopolitical uncertainties associated with petroleum dependency. In addition, tapping into biobased fuel sources, such as ethanol and biodiesel, expands that horizon considerably by supporting environmental stewardship by their renewable nature and carbon neutrality. North Carolina State University realizes the importance of achieving this biomass age and is therefore poised by virtue of its faculty, research mission, and resources to promote it and thereby improve the world.

\section{References}

1. J.T. Boepple. Petrochemicals, feedstocks. Kirk-Othmer encyclopedia of chemical technology [online]. John Wiley and Sons, Inc. Hoboken, N.J. Available from http://www.mrw. interscience.wiley.com/kirk/articles/petraubr.a01/frame.html. 2005.

2. C.J. Campbell. The end of cheap oil [online]. Available from http://dieoff.org/page140.htm. 1999.

3. Anonymous. Oil prices medium term [online]. Wikipedia. Available from http://en.wikipedia.org/wiki/Image:Oil_Prices_ Medium_Term.png. 2006.

4. M. Paster, J.L. Pellegrino, and T.M. Carole. Industrial bioproducts: today and tomorrow. Prepared by Energetics, Inc., Columbia, Maryland for the US Department of Energy, Office of Energy Efficiency and Renewable Energy, Office of the Biomass Program, Washington, D.C. 2003.

5. C.J. Campbell and J.H. Laherrère. The end of cheap oil. Sci. Am. March, 60-65 (1998).

6. D.H. Klass. Biomass for renewable energy, fuels, and chemicals. Acad. Press, San Diego, Calif. 1998. pp. 10-19.

7. C. Okkerse and H. van Bekkum. Green Chem. 1, 107 (1999).

8. Committee on Biobased Industrial Products, National Research Council, USA. Biobased industrial products: Priorities for research and commercialization. Natl. Acad. Press, Washington, D.C. 2000.
9. Biomass Energy Research Association [online]. Biomass Energy Research Association, Washington, D.C. Available from www.bera1.org. 2006

10. FAO. Global forest resources assessment 2000. Summary report [online]. Food and Agriculture Organisation, Rome, Italy. Available from www.fao.org/docrep/meeting/003/x9835e/ x9835e00.htm. 2001.

11. R. Matthews and K. Robertson. Answers to ten frequently answered questions about bioenergy, carbon sinks, and their role in global climate change [online]. International Energy Agency Bioenergy Task 38. Available from www. joanneum.at/iea-bioenergy-task38/publications/faq. 2001.

12. R.T. Watson, I.R. Noble, B. Bolin, N.H. Ravindranath, D.J. Verardo, and D.J. Dokken. (Editors). Intergovernmental Panel on Climate Change. Special report on land use, land-use change, and forestry. Intergovernmental Panel on Climate Change, Cambridge University Press, Cambridge, UK. 2000.

13. J. Chang. Vertec biosolvents on verge of breaking out with new replacement applications. Chem. Mark. Rep. 267, 42002.

14. US Department of Commerce. 1999 Annual survey of manufactures. US Census Bureau, Washington, D.C. 1999.

15. Chemical Market Report. Chemical profiles, ChemExpo [online]. Chem. Mark. Rep. Available from www.chemexpo.com. 2002.

16. Energetics, Inc. Biomass use for power, fuels, and products: Current use and trends. Energetics, Inc., Columbia, Md. April 2002.

17. M.A. Verespej. Winning technologies: polylactide polymers. Industry Week, Cleveland, Ohio. Dec. 2000.

18. Nature Works ${ }^{\circledR}$ LLC [online]. Nature Works ${ }^{\circledR}$ LLC, Minneapolis, Minn. Available from http://www.natureworksllc.com/corporate/news.asp.

19. S.K. Ritter. Chem. Eng. News 82, 22 (2004).

20. C. Fumagalli. Succinic acid and succinic anhydride. KirkOthmer encyclopedia of chemical technology. 4th Ed. Vol 22. John Wiley and Sons, Inc. Hoboken, N.J. 1997. pp. 1074 1088.

21. J.G. Zeikus, M.K. Jain, and P. Elankovan. Appl. Microbiol. Biotechnol. 52, 545 (1999).

22. B. Cornils and P. Lappe. Dicarboxylic acids. Ullmann's encyclopedia of industrial chemistry. 6th Ed. Vol. 10. 2003. pp. 525-526.

23. P.J. Weimer. Arch. Microbiol. 160, 288 (1993).

24. M.V. Guettler, D. Rumler, and M.K. Jain. Int. J. Syst. Bacteriol. 49, 207 (1999).

25. N.S. Samuelov, R. Lamed, S. Lowe, and J.G. Zeikus. Appl. Environ. Microbiol. 57, 3013 (1991).

26. Oak Ridge National Laboratory, Argonne National Laboratory, Pacific Northwest National Laboratory, National Renewable Energy Laboratory, and Applied Carbochemicals, Inc. Production of chemical derivatives from renewables: CRADA final report for CRADA ORNL 96-0407. November 1999.

27. Kirk-Othmer encyclopedia of chemical technology. 4th Ed. Vol. 6. John Wiley and Sons, Inc. Hoboken, N.J. 1997. pp. 353-359.

28. Th. Wilke and K.-D. Vorlop. Appl. Microbiol. Biotechnol. 56, 289 (2001).

29. K. Yahiro, S. Shibata, S.-R. Jia, Y. Park, and M. Okabe. J. Ferment. Bioeng. 84, 375 (1997).

30. H.L. Reid. Ind. Eng. Chem. 48, 1331 (1956).

31. B.V. Timokhin, V.A. Baransky, and G.D. Eliseeva. Russ. Chem. Rev. 68, 73 (1999).

32. W.A. Farone and J. Cuzens. US Patent 6/054/611, 24 April 2000. 
33. Q. Fang and M.A.Hanna. Bioresour. Technol. 81, 187 (2002).

34. P. Anastas, M. Kirchchoff, and T. Williamson. Green Chem. 1, G124 (1999).

35. US Environmental Protection Agency. Green chemistry [online]. US EPA, Washington, D.C. Available from http:// www.epa.gov/greenchemistry.

36. Institute for the Analysis of Global Security. P-Series fuels [online]. IAGS, Washington, D.C. Available from http:// www.iags.org/biofine.htm. 2004.

37. F.W. Lichtenthaler (Editor). Carbohydrates as organic raw materials. VCH Publishers, Weinheim, Germany. 1991.

38. G. Descotes (Editor). Carbohydrates as organic raw materials II. VCH Publishers, Weinheim, N.Y. 1993.

39. H. van Bekkum, H. Roper, and A.G.J. Voragen (Editors). Carbohydrates as organic raw Materials III. VCH Publishers, Weinheim, Germany. 1996.

40. H. Eierdanz (Editor). Perspektiven Nachwachsender Rohstofe in der Chemie. VCH Publishers, Weinheim, Germany. 1996.

41. F.W. Lichtenthaler and S. Mondel. Pure Appl. Chem. 69, 1853 (1997).

42. Introductory dedicational metaphor in: A. Hugill. Sugar and all that. A history of Tate and Lyle. Gentry Books, London. 1978.

43. R. Mullin. Chem. Eng. News, 82, 29 (2004).

44. M.A. Paisley. Biomass energy. Kirk-Othmer encyclopedia of chemical technology [online]. John Wiley and Sons, Inc. Hoboken, N.J. http://www.mrw.interscience.wiley.com/kirk/ articles/fuelklas.a01/frame.html. 2003.

45. J.E. Houck and P.E. Tiegs. Residential wood combustion review. Vol. 1. Technical Report. US Environmental Protection Agency, Office of Research and Development, Washington, D.C. 1998.

46. General Biomass Company [online]. Biomass, renewable en- ergy. General Biomass Company, Evanston, Ill. Available from www.generalbiomass.com/renew2.htm.

47. US Department of Energy. History of biofuels. US Department of Energy, Office of Transportation Technologies, Washington, D.C. 2002.

48. Department for Transport, UK. International resource costs of biodiesel and bioethanol [online]. Department of Transport, London, UK. Available from www.dft.gov.uk/stellent/groups/ dft_roads/documents/page/dft_roads_024054.hcsp [updated 29 June 2004]. 2003.

49. Renewable Fuels Association. How ethanol is made [online]. Renewable Fuels Association, Washington, D.C. Available from http://www.ethanolrfa.org/resource/made. 2005.

50. National Corn Growers Association [online]. National Corn Growers Association, Washington, D.C. Available from http://www.ncga.com/ethanol/main/production.htm. 2005.

51. ASTM. D6751 standard specification for biodiesel fuel (B100) blend [online]. American Society for Testing and Materials, West Conshohocken, Penn. Available from http:// www.astm.org.

52. National Biodiesel Board [online]. National Biodiesel Board, Jefferson City, Mo. Available from http://www.biodiesel.org. 2005.

53. US Department of Energy. Biomass program, renewable diesel fuel [online]. US Department of Energy, Energy Efficiancy and Renewable Energy, Washington, D.C. Available from http:// www.eere.energy.gov/biomass/renewable_diesel.html. 2005.

54. Soy Stats ${ }^{\mathrm{TM}}$. A reference guide to important soybean facts and figures [online]. American Soybean Association, Saint Louis, Mo. Available from http://www.soystats.com/2005/Defaultframes.htm. 2005.

55. Yokayo Biofuels. A history of biofuels [online]. Yokayo Biofuels, Ukiah, Calif. Available from www.ybiofuels.org. 2006. 
Copyright of Canadian Journal of Chemistry is the property of NRC Research Press and its content may not be copied or emailed to multiple sites or posted to a listserv without the copyright holder's express written permission. However, users may print, download, or email articles for individual use. 